\title{
Development of a process-based nitrogen mass balance model for a Virginia (USA) Spartina alterniflora salt marsh: implications for net DIN flux
}

\author{
Iris Cofman Anderson*, Craig R. Tobias, Betty Berry Neikirk, Richard L. Wetzel \\ School of Marine Science, Virginia Institute of Marine Science, College of William and Mary, Gloucester Point, \\ Virginia 23062, USA
}

\begin{abstract}
Primary production is nitrogen limited in most salt marshes with the possible exception of those impacted by high anthropogenic inputs of nitrogen. It is hypothesized that mature salt marshes which receive only small inputs of 'new' nitrogen from the atmosphere, surface water runoff, groundwater, tidal creek, and nitrogen-fixation will have a conservative nitrogen cycle. We have developed a process-based $\mathrm{N}$ mass balance model for a short-form Spartina alterniflora marsh in Virginia, USA. Data for the model included rates of gross mineralization, nitrification, denitrification, nitrogen fixation, above- and belowground macrophyte production, and benthic microalgal production. The annual balance between sources (mineralization, nitrogen fixation, tidal creek flux atmospheric deposition, and sediment input) and sinks (above- and belowground macrophyte uptake, sediment microalgal uptake, sediment burial, microbial immobilization, denitrification, and nitrification) of dissolved inorganic nitrogen (DIN) was determined for both interior $S$. alterniflora-vegetated sites and unvegetated creek bank sites. Sediment/water exchanges of DIN species, predicted by results of the mass balance analysis, were compared to measured exchanges. Annually, sources and sinks of DIN in the vegetated marsh were in close balance. The vegetated marsh imported DIN from the adjacent creek during most of the year; the unvegetated creek bank exported $\mathrm{NH}_{4}{ }^{+}$to overlying tidal water during July and imported $\mathrm{NH}_{4}{ }^{+}$during other seasons. The net flux of DIN was $5.7 \mathrm{~g} \mathrm{~N} \mathrm{~m}^{-2} \mathrm{yr}^{-1}$ from overlying water into the marsh; however, this flux was small relative to rates of internal $\mathrm{N}$-cycling processes. The sediment $\mathrm{NH}_{4}{ }^{+}$pool turned over rapidly as a result of the high rate of gross mineralization $\left(84 \mathrm{~g} \mathrm{~N} \mathrm{~m}^{-2} \mathrm{yr}^{-1}\right)$. Other microbial $\mathrm{N}$-cycling rates were low 0.6 to $\left.4 \mathrm{~g} \mathrm{~N} \mathrm{~m}^{-2} \mathrm{yr}^{-1}\right)$. The $\mathrm{NH}_{4}^{+}$supplied by mineralization was more than sufficient to support both macrophyte $\left(33 \mathrm{~g} \mathrm{~N} \mathrm{~m}^{-2} \mathrm{yr}^{-1}\right)$ and benthic microalgal $\left(5 \mathrm{~g} \mathrm{~N} \mathrm{~m}^{-2}\right.$ $\mathrm{yr}^{-1}$ ) uptake. We propose that in order to maintain steady state in the system approximately half of the DIN mineralized is immobilized into a readily remineralizable particulate organic $N$ pool. Since mineralization and macrophyte uptake are temporally out of phase, the labile organic $N$ pool may serve to temporarily sequester $\mathrm{NH}_{4}{ }^{+}$until it is required for plant uptake.
\end{abstract}

KEY WORDS: Salt marsh Mineralization - Immobilization - Nitrogen cycling Nitrification/denitrification DIN flux

\section{INTRODUCTION}

Salt marshes have been hypothesized to play numerous critical roles in the estuarine environment including support of living resources and buffering of the effects of nutrient inputs. It has been proposed that export (outwelling) matter from salt marshes may support primary and secondary production crucial for the

-E-mail: iris@vims.edu maintenance of fisheries (Teal 1962, de la Cruz 1965, Odum \& de la Cruz 1967, Turner \& Boesch 1988). Salt marshes have also been characterized as efficient sinks for nutrients protecting adjacent estuaries from surface water runoff. Nixon (1980) pointed out the lack of quantitative evidence supporting the outwelling hypothesis. In the intervening decades many researchers have tried to quantify exchanges that occur between marshes and adjacent waters and determine the currency of that export. 
Many studies have shown that production of Spartina alterniflora is limited by nitrogen availability (Valiela \& Teal 1974, Patrick \& DeLaune 1976, Morris 1982, Dai \& Wiegert 1996b) and other factors such as high salinity, low dissolved oxygen and high sulfide concentrations (Morris 1980). Thus, one would expect that during times of high macrophyte or benthic microalgal production marshes will serve as sinks for dissolved inorganic nitrogen (DIN) from tidal water. During periods of macrophyte decomposition the marsh may serve as a source of nitrogen to tidal water depending upon the amount of nitrogen lost from aboveground biomass by. processes such as leaching (Turner 1993), the amount of nitrogen translocated from aboveto belowground biomass (Hopkinson \& Schubauer 1984), the turnover rate of the biomass, and rates of microbial mineralization, immobilization, coupled nitrification-denitrification, dissimilatory nitrate reduction to ammonium, and nitrogen fixation. In addition to these biotic factors, tidal range, pore water drainage (Whiting \& Childers 1989, Howes \& Goehringer 1994), temperature, insolation, freshwater influence, nutrient availability, geologic age, ratio of sediment importexport, marsh topography and elevation, and exposure to open water (Dame \& Kenny 1986, Childers et al. 1993a) can all affect nitrogen processing and, thus, exchanges of nitrogen between marshes and estuarine waters.

A variety of techniques have been used to quantify marsh-water exchanges. For example, flume studies, which integrate biotic and physicochemical influences, (Wolaver et al. 1983, Bowden 1986, Childers \& Day 1988, Whiting et al. 1989, Childers et al. 1993a, Dame \& Gardner 1993, Childers 1994) have shown that both the magnitude and direction of exchanges are highly variable and are affected by factors such as geological age and tidal range (Childers et al. 1993a, Dame \& Gardner 1993). Measurements of dissolved and particulate nutrient concentrations and volume of water exchanged, performed in a number of creeks along the east coast, have for the most part shown a net import of $\mathrm{NO}_{3}{ }^{-}$and export of dissolved organic nitrogen (DON); however, results with respect to $\mathrm{NH}_{4}{ }^{+}$were highly variable (Axelrad 1974, Moore 1974, Valiela et al, 1978). Childers et al. (1993b), using a tidal hydrology model combined with flux data to determine net daily exchanges in the North Inlet, South Carolina, USA, estuary, demonstrated net annual marsh uptake of both $\mathrm{NH}_{4}^{+}$and $\mathrm{NO}_{3}^{-}$plus $\mathrm{NO}_{2}^{-}$. What was lacking in most of these studies were contemporaneous measurements of marsh processes and nutrient exchanges between the marsh surface and overlying water and between the tidal creek and estuary. Use of in situ chambers (Scudlark \& Church 1989, Chambers 1992, Neikirk 1996) to measure fluxes between marsh sediments and overlying water may provide an improved understanding of the relationships between marsh sediment processes and net marsh-water exchanges.

In this study we have combined measurements of microbial $\mathrm{N}$-cycling rates with estimates of above- and belowground macrophyte production, benthic microalgal production, and physical exchanges with the tidal creek, upland, and atmosphere to construct annual inorganic nitrogen budgets for the vegetated and unvegetated zones of a short-form Spartina alterniflora marsh. In particular, we address the implications of these budgets for net fluxes of nitrogen between the marsh and adjacent tidal creek. Concurrent with this work we measured net exchanges of dissolved inorganic and organic nutrients between the salt marsh sediment surface and overlying creek water, and changes in water column nutrients in the tidal creek over tidal cycles (Neikirk 1996).

\section{SITE DESCRIPTION}

The Virginia Coast Reserve (VCR) is a National Science Foundation Long Term Ecological Research Site managed by the Nature Conservancy. The mainland portion of the reserve is a complex assemblage of forests, agricultural fields, and contiguous fringing marshes. Shallow lagoons with deep channels, mud flats, and expansive salt marshes separate the mainland marshes from 14 barrier islands fronting the Atlantic Ocean. The VCR extends $110 \mathrm{~km}$ along the seaward margin of the southern Delmarva Peninsula. Our study site, Phillips Creek Marsh, is located in a mainland salt marsh of approximately 135 ha (MacMillin et al. 1992) which drains into Phillips Creek. Annually tidal range at this site is approximately $1.93 \mathrm{~m}$ relative to mean sea level (MSL). The marsh is dominated by the short form of Spartina alterniflora ( 0.4 to $0.6 \mathrm{~m}$ stem height). Salinities in overlying tidal water varied from 26 to 33 ppt. Creek banks are vegetated with medium-form $S$. alterniflora $(0.9$ to $1.3 \mathrm{~m}$ stem height) interspersed with unvegetated areas

\section{METHODS}

Field sampling. In order to minimize disturbance to the marsh, boardwalks $(20 \mathrm{~m})$ were constructed parallel to the creek bank both in an unvegetated zone at the edge of the creek and in an interior vegetated zone. Boardwalks defined sampling transects. Sites along each boardwalk were surveyed with reference to MSL, and inundation times for each of the sites determined using measurements in the VCR data base of hourly tides in a neighboring tidal creek (Redbank) referenced to MSL (T. Christensen pers. comm.). 
Sampling was done seasonally (October, February, May, July) at low tide during a $2 \mathrm{yr}$ period. Since sampling was destructive, we chose to take cores at $0.5 \mathrm{~m}$ intervals from a randomly chosen starting point along each of the $20 \mathrm{~m}$ transects in the marsh. An additional moveable plank $(4.6 \mathrm{~m})$ was laid perpendicular to the transect to increase the area available for collection of cores. All sediment physical-chemical analyses were performed in quintuplicate. Process measurements were run in triplicate, over 3 incubation periods, and in some cases both in the light and in the dark. Replicate cores were chosen randomly from the total pool of cores collected along each transect.

Unless otherwise noted, field samples for physicalchemical analyses or process rate measurements were taken by hand using polycarbonate tubes with a cross sectional area of $25.5 \mathrm{~cm}^{2}$. For determinations of sediment properties cores were taken to a depth of $20 \mathrm{~cm}$; for rate processes cores were 3 to $4 \mathrm{~cm}$ in depth. Plexiglass plates fitted with 2 stopcocks sealed the tops of the core tubes allowing light to enter. Holes were drilled down the length of the core at $0.5 \mathrm{~cm}$ intervals with alternate rows offset by $90^{\circ}$ and filled with silicone.

Physical-chemical analyses. Dissolved inorganic nitrogen (DIN) analyses: Sediment was extracted with 1.5 volumes of $\mathrm{KCl}(2 \mathrm{M})$, shaken on a rotary shaker for $1 \mathrm{~h}$ at room temperature, and centrifuged. Supernatants were filter sterilized (Gelman Supor $0.2 \mu \mathrm{m}$ filters) and stored refrigerated in sterile serum bottles until analyzed. $\mathrm{NH}_{4}{ }^{+}$was determined by the technique of Solorzano (1969). $\mathrm{NO}_{3}{ }^{-}$was reduced to $\mathrm{NO}_{2}{ }^{-}$using a cadmium reduction column and determined by diazotization using an Alpkem 'Flow Solution' autoanalyzer (Perstorp 1992)

Bulk sediment properties: Wet bulk density was measured by weighing $2 \mathrm{~cm}$ sections of cores, which were dried at $60^{\circ} \mathrm{C}$ to constant weight and reweighed to determine \% water, dry weight (DW), and dry bulk density.

Sediment chlorophyll a: Twelve sediment cores (2.54 cm diameter) were taken bimonthly along the transect through the interior vegetated site. Cores from the unvegetated site were taken only during July and December. The 0 to $5 \mathrm{~mm}$ section of each core was removed and stored frozen $\left(-20^{\circ} \mathrm{C}\right)$ until analyzed. Analysis was performed according to the protocol of Lorenzen (1967), as modified by Pinckney \& Zingmark (1994) to include extraction of the sediment (unground) with a mixture of solvents ( $45 \%$ methanol, $45 \%$ acetone, $10 \%$ deionized water) at $-15^{\circ} \mathrm{C}$ for $>1 \mathrm{wk}$.

Carbon and nitrogen content: Vegetated and unvegetated sediments, Spartina alterniflora leaves, roots, and rhizomes were sampled during May, July, December, 1994, and August, 1995. Samples were ground in a Wiley mill with 40 -mesh screen and were analyzed using a Control Equipment Corporation, model 440 elemental analyzer.

Sediment temperature: Sediment temperature at field sites during sampling was determined using a thermistor at $1 \mathrm{~cm}$ depth

Measurements of nitrogen cycling rates. Nitrogen fixation: This was determined by acetylene $\left(\mathrm{C}_{2} \mathrm{H}_{2}\right)$ reduction to ethylene $\left(\mathrm{C}_{2} \mathrm{H}_{4}\right)$. Intact cores (18) were removed from both vegetated marsh and unvegetated creek bank and left overnight open to ambient air The following day they were injected with $\mathrm{CaC}_{2}$-generated $\mathrm{C}_{2} \mathrm{H}_{2}$-saturated, filtered creek water to give a final $\mathrm{C}_{2} \mathrm{H}_{2}$ concentration of $10 \%$ in sediment pore water. Triplicate cores were incubated for 0,3 , and $6 \mathrm{~h}$ in the light and dark at ambient water temperature. Incubations were terminated by addition of a volume of $2 \mathrm{M}$ $\mathrm{KCl}$ equal to that of the sediment with shaking for 1 min. Headspace gas was removed for analysis of $\mathrm{C}_{2} \mathrm{H}_{4}$. Ethylene analyses were performed by gas chromatography (Shimadzu, Model 14), using a flame ionization detector at $200^{\circ} \mathrm{C}$ and Poropak T column (2 m) at $80^{\circ} \mathrm{C}$. For calculation of $\mathrm{N}$-fixation rates we assumed that 1 mole of $\mathrm{N}_{2}$ was fixed for every 3 moles of $\mathrm{C}_{2} \mathrm{H}_{2}$ reduced to $\mathrm{C}_{2} \mathrm{H}_{4}$.

Gross mineralization: This was determined by ${ }^{15} \mathrm{NH}_{4}{ }^{+}$isotope pool dilution as described in Davidson et al. (1990). For each experiment 9 cores were injected with $0.7 \mathrm{ml}$ argon-sparged $\left({ }^{15} \mathrm{NH}_{4}\right)_{2} \mathrm{SO}_{4}$ to a final concentration of $100 \mu \mathrm{M}$ and 30 atom $\%{ }^{15} \mathrm{~N}$ enrichment in pore water. Cores were incubated under ambient conditions of temperature and light for $0,3,6 \mathrm{~h}$, except during February when incubation times were 0,4 , and $8 \mathrm{~h}$. After incubation 3 cores were sacrificed by addition of an equal volume of $2 \mathrm{M} \mathrm{KCl}$. Sediment slurries were shaken for $1 \mathrm{~h}$ on a rotary shaker at room temperature and centrifuged. Supernatants were filter sterilized (Gelman Supor $0.2 \mu \mathrm{m}$ filters), stored refrigerated in autoclaved serum bottles until analyzed for $\mathrm{NH}_{4}{ }^{+}, \mathrm{NO}_{3}{ }^{-}$, and $\mathrm{NO}_{2}{ }^{-}$as described above. Remaining supernatants were then transferred to sterile, disposable specimen cups. After addition of $\mathrm{MgO}(0.2 \mathrm{~g})$ $\mathrm{NH}_{4}{ }^{+}$was trapped on acidified $\left(\mathrm{KHSO}_{4}, 10 \mu \mathrm{l}, 2.5 \mathrm{M}\right.$ ) paper filters (Whatman $\# 3,7 \mathrm{~mm}$ ), as described by Brooks et al. (1989). Disks were dried overnight in a desiccator over concentrated sulfuric acid, wrapped in tin capsules, and shipped to the University of California, Berkeley, USA (Department of Soil Science) for analysis of ${ }^{15} \mathrm{~N}$ enrichment using an isotope ratio mass spectrometer (Europa), linked to a $\mathrm{C} / \mathrm{N}$ analyzer. Rates of mineralization were determined using the model described by Wessel \& Tietema (1992), which takes into account both the change in at. \% enrichment of the ${ }^{15} \mathrm{~N}$-labelled pool as well as the change in total concentration of that pool $\left({ }^{15} \mathrm{~N}+{ }^{14} \mathrm{~N}\right)$. 
Nitrification: This was determined by ${ }^{15} \mathrm{NO}_{3}^{-}$isotope pool dilution. Measurements were performed as described for mineralization with the following modifications. Cores (18 per transect) were injected with $0.7 \mathrm{ml}$ argon-sparged $\mathrm{K}^{1.5} \mathrm{NO}_{3}$ to a final concentration of $1 \mathrm{mM}$ and 30 at. $\%{ }^{15} \mathrm{~N}$ enrichment. Incubation times were $0,3,6 \mathrm{~h}$ during spring, summer, and fall and 0,4 and $8 \mathrm{~h}$ during winter and usually were conducted both in the light and in the dark. ${ }^{15} \mathrm{NH}_{4}{ }^{+}$produced by dissimilatory nitrate reduction was collected on acidified filter paper as described above. Devarda's alloy $(0.4 \mathrm{~g})$ was then added to the supernatant, causing reduction of ${ }^{15} \mathrm{NO}_{3}^{-}$to ${ }^{15} \mathrm{NH}_{4}{ }^{+}$The ${ }^{15} \mathrm{NH}_{4}{ }^{+}$was similarly collected by diffusion onto acidified filter paper disks for $6 \mathrm{~d}$.

Denitrification: This was determined by ${ }^{15} \mathrm{~N}_{2} \mathrm{O}$ isotope pool dilution. Cores (18 per transect) were injected with $0.7 \mathrm{ml}$ of ${ }^{15} \mathrm{~N}_{2} \mathrm{O}$ in argon-sparged, filtered $(0.2 \mu \mathrm{m}$ Gelman Supor filters) creek water to provide a final concentration of $2 \mu \mathrm{l}^{-1}$ in the pore water at 30 at. $\%{ }^{15} \mathrm{~N}$ enrichment. Cores were incubated under conditions of ambient light and temperature for 0,1 , and $2 \mathrm{~h}$. Following incubation $51 \mathrm{ml}$ of $\mathrm{KCl}(2 \mathrm{M})$, approximately equal to the volume of sediment, was added. The syringe was left in place and pressure in the core tube relieved by venting headspace gas into a second syringe which was also left attached to the stopcock on the top of the core tube. The sediment slurry was shaken for $1 \mathrm{~min}$ to equilibrate gas in the pore water with that in the headspace. The headspace gas was mixed with that in the syringes. A $20 \mathrm{ml}$ sample was transferred to an argon-sparged and evacuated $(2 x)$ Hungate tube $(13 \mathrm{ml})$ which was shipped to the University of California, Berkeley for analysis of at. $\%{ }^{15} \mathrm{~N}$ by the method described by Brooks et al. (1993). A second sample of headspace gas was analyzed for nitrous oxide $\left(\mathrm{N}_{2} \mathrm{O}\right)$ concentration using a Shimadzu, Model 8 gas chromatograph fitted with an electron capture detector at $330^{\circ} \mathrm{C}$ and Poropak Q column $(2 \mathrm{~m})$ at $50^{\circ} \mathrm{C}$. Concentrations were corrected for gas in the dissolved phase and for salinity using the Oswald coefficient as described by Weiss \& Price (1980)

Measurements of carbon cycling processes. Gross primary production by benthic microalgae: Production was estimated by making bimonthly measurements of chlorophyll $a$ in the upper $5 \mathrm{~mm}$ of sediment as described above. Based upon these measures of sediment microalgal biomass and assuming that conditions in the short-form Spartina alterniflora marshes located in Virginia and South Carolina (SC), were similar, we estimated annual microalgal production using a model developed by J. L. Pinckney for North Inlet, SC, shortform S. alterniflora marshes (Pinckney 1994). This model relates production to chlorophyll a biomass. Pinckney's model takes into account irradiance beneath the canopy, which was estimated using a light attenuation model developed by Morris (1989) as well as photophysiological responses of the microalgae, vertical migration periodicity, and photosynthetic biomass.

To compare model predictions with in situ measurements, we determined microalgal production directly during a $3 \mathrm{~d}$ period in July using chambers $(0.5 \mathrm{l})$ to measure $\mathrm{CO}_{2}$ exchanges in the light and dark. Headspace gas was circulated continuously through a LiCor, model 6252, infrared gas analyzer for $5 \mathrm{~min}$ periods for determination of $\mathrm{CO}_{2}$ concentrations. Irradiance $\left(\mu \mathrm{E} \mathrm{m}^{-2} \mathrm{~s}^{-1}\right)$ on the outside surface of the chamber (irradiance inside was $10 \%<$ outside) was concurrently measured using a $2 \pi$ LiCor sensor. For the purposes of verifying use of the model, which was designed to calculate annual production, we compared estimates of production using the model (with our measurements of chlorophyll a during July as input data) with those made by gas exchange (taking into account a $12 \mathrm{~h}$ light period and $3 \mathrm{~h}$ tidal inundation during daytime which reduced production by $25 \%$ ).

Net Spartina alterniflora above- and belowground production and turnover: Rates of above- and belowground production were based upon peak biomass measured during July-August (performed in quintuplicate). All aboveground biomass within a $0.1 \mathrm{~m}^{2}$ quadrat was clipped, separated into live and dead fractions, and dried at $60^{\circ} \mathrm{C}$ to constant weight. One core $14.2 \mathrm{~cm}$ radius) to a depth of $30 \mathrm{~cm}$ was taken within each quadrat. Sediment was removed from plant samples by rinsing over a $2 \mathrm{~mm}$ sieve. Belowground macro-organic matter (MOM), which included both live and dead material, was dried at $60^{\circ} \mathrm{C}$ to constant weight. In order to estimate the rate of turnover and decomposition of MOM we used measurements of root ingrowth into litter bags as well as root + rhizome decomposition made by Blum (1993) at a site close to ours.

Determination of $Q_{10}$ value for community respiration: Cores were taken from the short Spartina alterniflora zone of Phillips Creek Marsh and placed into water jacketed core tubes. Water temperature was varied over the range 15 to $35^{\circ} \mathrm{C}$, and $\mathrm{CO}_{2}$ production determined with a LiCor 6252 infrared gas analyzer. $Q_{14}$ was calculated as the change in rate of $\mathrm{CO}_{2}$ production over a $10^{\circ} \mathrm{C}$ temperature range.

Physical exchanges. Groundwater discharge: In order to assess the potential affect of groundwater discharge on the nitrogen budget of the Spartina alterniflora marsh, we measured salinity and $\mathrm{NO}_{3}{ }^{-}$concentrations in shallow groundwater and pore water near and under the marsh and seepage rates to the bottom of the adjacent creek. Groundwater samples were collected in June 1995 at the upland-marsh edge using a driven piezometer (Winter et al. 1991) or from springs which bypassed the marsh and discharged directly into the creek. Ten locations were sampled over a distance of approx- 
imately $1000 \mathrm{~m}$ of marsh border. Pore waters were sampled to a depth of $25 \mathrm{~cm}$ beneath the study site using diffusion samplers and to a depth of $2 \mathrm{~m}$ below the creek bed adjacent to the study site using piezometers in March 1994 and April 1995. Creek water samples were collected concurrently for comparison of salinity and nitrate concentrations. Seepage meters were deployed in April 1995 (typically a period of high groundwater flow) in the creek in order to quantify ground water seepage rates. Estimates of the magnitude of groundwater flux were calculated by changes in volume and salinity of the water collected in the seepage meter collection reservoir (Lee \& Cherry 1978. Libelo \& MacIntyre 1994).

Sediment water exchanges: Fluxes of DIN, DON, and DOC (dissolved organic carbon) between sediments and overlying tidal water were measured by Neikirk (1996) along the vegetated transect at bimonthly intervals and along the unvegetated transect during July, November, and February. For these measurements, Neikirk deployed 9 chambers $(0.61 \mathrm{~m}$ high $\times 30.48 \mathrm{~cm}$ diameter), 5 without bottoms, 4 with bottoms at fixed points along the transect. Chambers were allowed to fill through holes near their base at the sediment surface. When water height in the chambers reached approximately $12 \mathrm{~cm}$, the holes were plugged, stirrers were started, and water was sampled at $20 \mathrm{~min}$ intervals over a $2 \mathrm{~h}$ period. All flux measurements were performed during daylight hours.

Determination of inundation time. Hourly tidal heights relative to MSL for Red Bank Creek, into which Phillips Creek flows, were obtained from the VCR database (Krovitz et al 1994, 1995) and used to calculate daily inundation times for our study sites whose elevations were also referenced to a benchmark at MSL (T. Christensen pers. comm.).

Statistical methods. The non-parametric MannWhitney $U$-test was used to compare means of sediment nutrient concentrations between pairs of months and between unvegetated and vegetated sites for a single month

\section{RESULTS}

\section{Physical-chemical properties and rate estimates}

Sediment nutrients and bulk properties

During May, July, and October 1994, $\mathrm{NH}_{4}{ }^{+}$was significantly higher in unvegetated than in vegetated sedi- ments whereas $\mathrm{NO}_{3}{ }^{-}$was significantly higher $(p<0.05)$ in vegetated than in unvegetated sediments during February and July 1994 (Table 1). Ammonium generally increased from winter through fall with concentrations significantly higher $(\mathrm{p}<0.05)$ in October than all other months except July 1993 (vegetated only) at both vegetated and unvegetated sites. Bulk density was significantly higher in unvegetated sites during February and significantly lower during October $(p<0.05)$.

\section{Microbial nitrogen cycling rates}

Mineralization was the dominant process with rates (81 to $382 \mathrm{ng} \mathrm{N} \mathrm{g}^{-1} \mathrm{DW} \mathrm{h}^{-1}$ ) an order of magnitude or more greater than all other $\mathrm{N}$-cycling processes. (Microbial nitrogen cycling rates shown in Table 2.) Nitrification rates ( 0 to $115 \mathrm{ng} \mathrm{N} \mathrm{g}^{-1} \mathrm{DW} \mathrm{h}^{-1}$ ) were generally almost an order of magnitude lower than mineralization rates except during May when rates at the unvegetated site approached mineralization rates. Using a ${ }^{15} \mathrm{~N}_{2} \mathrm{O}$ isotope pool dilution technique, denitrification rates were very low ( 0 to $2.29 \mathrm{ng} \mathrm{N} \mathrm{g}^{-1} \mathrm{DW} \mathrm{h}^{-1}$ ) relative to mineralization and nitrification. Rates of sediment nitrogen fixation ( 0.3 to $7.5 \mathrm{ng} \mathrm{Ng}^{-1} \mathrm{DW} \mathrm{h}^{-1}$ ) measured by acetylene reduction to ethylene were generally 1 to 2 orders of magnitude lower than rates of mineralization and were approximately equal to denitrification.

\section{Biomass and production estimates}

Macrophyte biomass

Peak live plus dead aboveground biomass (AGB) constituted only a small percentage ( 5 to $9 \%$ ) of the below- 
Table 2. Microbial nitrogen cycling rates (ng $\mathrm{N} \mathrm{g}^{-1} \mathrm{DW} \mathrm{h}^{-1}$ ). Veg: Spartina alterniflora marsh; unveg: unvegetated creekbank site. ND: not determined. Standard errors given in parentheses; $n=3$ except for mineralization where $n=6$

\begin{tabular}{|llcccc|}
\hline Date & Site $^{\text {d }}$ & Mineralization & Nitrification & N-fixation & Denitrification \\
\hline Jul 93 & Veg-L & $125(39)$ & $39(17)$ & ND & $0.62(0.14)$ \\
& Unveg-L & $188(21)$ & $8(8)$ & ND & $1.23(0.63)$ \\
Jul 94 & Veg-D & $103(28)$ & $8(3)$ & $3.6(1.1)$ & $0.84(0.09)$ \\
& Veg-L & $245(65)$ & $0(0)$ & $7.5(2.2)$ & 0 \\
& Unveg-D & $236(84)$ & $10(2)$ & $1.5(0.2)$ & 0 \\
& Unveg-L & $243(83)$ & $13(4)$ & $0.5(0.3)$ & $2.29(0.45)$ \\
May 94 Veg-D & $N D$ & $N D$ & $4.1(3.1)$ & ND \\
& Veg-L & $208(37)$ & $63(14)$ & $6.5(0.6)$ & $1.51(0.43)$ \\
& Unveg-L & $123(10)$ & $115(35)$ & 0.7 & $0.45(0.46)$ \\
Feb 94 Veg-D & $81(14)$ & $20(5)$ & 1.4 & $0.43(0.15)$ \\
& Unveg-D & $96(26)$ & $9(2)$ & $0.3(0.01)$ & $0.25(0.16)$ \\
Oct 94 & Veg-D & $242(29)$ & $0(0)$ & $2.7(1.0)$ & $1.12(0.25)$ \\
& Unveg-D & $382(101)$ & $0(0)$ & $0.6(0.2)$ & $0.56(0.40)$ \\
aSamples from sites marked with L incubated at ambient light and with D \\
incubated in the dark
\end{tabular}

ground MOM (live plus dead, partially decomposed plant material) available for decomposition by microorganisms (Table 3). Percent nitrogen relative to carbon in leaves and roots showed a dramatic decline between summer and winter.

\section{Benthic microalgal biomass and production}

An annual rate of production of $27.8 \mathrm{~g} \mathrm{C} \mathrm{m}^{-2}$ or annual nitrogen demand of $4.9 \mathrm{~g} \mathrm{~N} \mathrm{~m}^{-2}$ was calculated using the benthic microalgal production model of Pinckney (1994) along with our sediment chlorophyll a values (Table 4 ).
To validate use of Pinckney's model for Phillips Creek Marsh, consecutive measurements of sediment $\mathrm{CO}_{2}$ exchange were performed during July in the light and dark. Average irradiances (mean, SE, $\mathrm{n}=3$ ) were 778 (138), 574 (164), and 1178 (128) $\mu \mathrm{E} \mathrm{m}^{-2} \mathrm{~s}^{-1}$. For all measurements (light and dark) there was net release of $\mathrm{CO}_{2}$ from the sediments. Average sediment gross primary production was $0.16 \mathrm{~g} \mathrm{C} \mathrm{m}^{-2} \mathrm{~d}^{-1}$ ( $\mathrm{SE}=$ $0.04 ; \mathrm{n}=9$ ). Production was corrected for $25 \%$ decreased productivity (estimated by Pinckney) during inundation. When extrapolated to an annual production rate, these July measurements (mean daily rate $\times 365$ ) would yield an annual production rate of $58.4 \mathrm{~g} \mathrm{C} \mathrm{m}^{-2}$ $\mathrm{yr}^{-1}$ compared to $45.4 \mathrm{~g} \mathrm{C} \mathrm{m}^{-2} \mathrm{yr}^{-1}$, estimated using Pinckney's model.

\section{Physical exchanges}

\section{Groundwater discharge}

Most groundwater samples showed variably lower salinities and consistently lower $\mathrm{NO}_{3}{ }^{-}$concentrations relative to creek water. Excluding samples collected from or near springs, salinities and $\mathrm{NO}_{3}{ }^{-}$concentrations in groundwater collected along the upland-marsh border averaged $17.7 \mathrm{ppt}$ (range $=9$ to $26 \mathrm{ppt}$ ) and $1.73 \mu \mathrm{M} \mathrm{NO}_{3}^{-}$(range $=1.14$ to $2.44 \mu \mathrm{M}$ ). Samples col-

Table 3. Macrophyte and sediment characteristics. Sediment (veg): sediment from interior marsh site vegetated with Spartina alterniflora. Sediment (cb): sediment from unvegetated creekbank site. Standard errors given in parentheses; $\mathrm{n}=5$

\begin{tabular}{|c|c|c|c|c|c|c|c|}
\hline \multirow[t]{3}{*}{ Date } & \multirow[t]{3}{*}{ Sample } & \multicolumn{3}{|c|}{ Biomass $\left(\mathrm{g}^{-1} \mathrm{DW} \mathrm{m}^{-2}\right)$} & \multirow{3}{*}{ Total $C^{d}$} & \multirow{3}{*}{$(\%)$} & \multirow[t]{3}{*}{ Total $\mathrm{N}^{\mathrm{d}}$} \\
\hline & & Abo & ound & Belowground & & & \\
\hline & & Live & Dead & Live + Dead & & & \\
\hline \multirow[t]{2}{*}{ May 94} & Sediment (veg) & & & & $2.47(0.09)$ & & $0.23(0.01)$ \\
\hline & Sediment $(\mathrm{cb})$ & & & & $2.27(0.16)$ & & $0.18(0.01)$ \\
\hline \multirow[t]{6}{*}{ Jul 94} & Vegetation & $374\{60\}$ & & $6560(1092)$ & & & \\
\hline & Leaves & & & & 31.80 & & 2.56 \\
\hline & Roots & & & & 39.25 & & 1.25 \\
\hline & Rhizomes & & & & 29.93 & & 0.79 \\
\hline & Sediment (veg) & & & & $2.82(0.12)$ & & $0.22(0.01)$ \\
\hline & Sediment $(c b)$ & & & & $2.46(0.25)$ & & $0.17(0.02)$ \\
\hline \multirow[t]{4}{*}{ Dec 94} & Vegetation & $75(14)$ & $204(11)$ & $5455(1274)$ & & & \\
\hline & Leaves & & & & 40.44 & & 0.98 \\
\hline & Roots & & & & 25.37 & & 0.69 \\
\hline & Rhizomes & & & & 38.14 & & 0.52 \\
\hline \multirow[t]{3}{*}{ Aug 95} & Vegetation & $479(26)$ & $63(10)$ & $5874(217)$ & & & \\
\hline & Leaves & & & & $47.48(0.89)$ & & $1.72(0.15)$ \\
\hline & Roots + Rhizomes & & & & $42.59(0.89)$ & & $1.49(0.07)$ \\
\hline
\end{tabular}


Table 4. Sediment chlorophyll and microalgal production. Veg: Spartina alterniflora marsh; unveg: unvegetated creekbank site. Standard errors given in parentheses; $\mathrm{n}=10$

\begin{tabular}{|c|c|c|c|c|}
\hline Date & Site & $\begin{array}{l}\text { Chlorophyll }(0-5 \mathrm{~mm}) \\
\left(\mathrm{mg} \mathrm{chl} a \mathrm{~m}^{-2}\right)\end{array}$ & $\begin{array}{l}\text { Production } \\
\left(\mathrm{g} \mathrm{C} \mathrm{m}^{-2} \mathrm{yr}^{-1}\right)\end{array}$ & $\begin{array}{l}\mathrm{N} \mathrm{demand} \mathrm{d}^{\mathrm{b}} \\
\left(\mathrm{g} \mathrm{N} \mathrm{m^{-2 }} \mathrm{yr}^{-1}\right)\end{array}$ \\
\hline Mar 94 & Veg & $16.3(2.1)$ & $52.3(6.7)$ & $9.2(1.2)$ \\
\hline May 94 & Veg & $7.4(1.9)$ & $23.6(6.1)$ & $4.2(1.1)$ \\
\hline \multirow[t]{2}{*}{ Jul 94} & Veg & $14.2(1.6)$ & $45.4(5.1)$ & $8.0(0.9)$ \\
\hline & Unveg & $4.1(0.3)$ & $13.1(1.0)$ & $2.3(0.2)$ \\
\hline Sep 94 & Veg & $6.9(1.0)$ & $22.1(3.2)$ & $3.9(0.6)$ \\
\hline \multirow{2}{*}{ Dec 94} & Veg & $10.5(0.9)$ & $33.6(2.9)$ & $5.9(0.5)$ \\
\hline & Unveg & $3.5(0.7)$ & $11.2(2.2)$ & $2.0(0.4)$ \\
\hline Feb 95 & Veg & $6.7(1.1)$ & $21.3(3.5)$ & $3.8(0.6)$ \\
\hline \multicolumn{2}{|c|}{ Annual means } & $8.7(1.6)$ & $27.8(3.8)$ & $4.9(0.7)$ \\
\hline \multicolumn{5}{|c|}{$\begin{array}{l}\text { annual production based upon sediment chlorophyll measured for that } \\
\text { month, using model of Pinckney (1994) } \\
{ }^{b} \text { Conversion from } \mathrm{C} \text { units to } \mathrm{N} \text { units based upon the Redfield ratio of } 5.68 \mathrm{~g} \\
\text { C perg N }\end{array}$} \\
\hline
\end{tabular}

were performed only sporadically and were highly variable; however, these sediments were a source of $\mathrm{NH}_{4}{ }^{+}$to the creek during July when sediment concentrations were high and a sink for $\mathrm{NO}_{3}{ }^{-}$and $\mathrm{NO}_{2}{ }^{-}$during February when creek water concentrations were high.

\section{Development of a nitrogen mass balance model for Phillips Creek Marsh}

In developing the $N$ mass balance model for Phillips Creek Marsh we have made the following assumptions and calculations: lected concurrently from Phillips Creek had both higher salinity (24 ppt) and higher $\mathrm{NO}_{3}{ }^{-}$concentrations (5.58 $\mu \mathrm{M})$. Groundwater collected from springs and beneath an eroding creek bank with highly conductive soils, 150 and $300 \mathrm{~m}$ from our study site, contained 137 and $56 \mu \mathrm{M} \mathrm{NO}_{3}{ }^{-}$respectively. Immediately adjacent to the study site pore waters below the creek bed at low tide exhibited a 3 to 6 ppt salinity depression and less than $4 \mu \mathrm{M} \mathrm{NO}_{3}{ }^{-}$elevation relative to tidal flooding water $\mathrm{NO}_{3}^{-}$. Sampling of pore waters under the marsh study site using a piezometer was unsuccessful due to the low hydraulic conductivity of the marsh sediment $\left(\mathrm{K}<10^{-4} \mathrm{~cm} \mathrm{~s}^{-1}\right.$ ). However, pore water samples taken with diffusion samplers to a depth of $24 \mathrm{~cm}$ showed average $\mathrm{NO}_{3}^{-}$concentrations less than $2.0 \mu \mathrm{M}$. No detectable water flux was observed using seepage meters placed in the creek bed adjacent to the site over a tidal cycle.

\section{Exchanges of DIN and DOC between} marsh sediments and overlying tidal water

Exchanges of DIN and DOC between sediments and overlying tidal water, measured by Neikirk (1996), were used to calculate monthly and annual fluxes, using inundation times calculated from hourly tidal heights in the VCR database (Krovitz et al. 1994/1995) (Table 5). Fluxes due to phytoplankton uptake or release in water column-only chambers were subtracted before calculating the sediment-water column exchange rates. During all seasons vegetated marsh sediments were a sink for DIN; there were no statistically significant net exchanges of DOC (data not shown). Determinations of DIN exchanges between the unvegetated creek bank sediments and the creek
Sources of dissolved inorganic nitrogen to Phillips Creek Marsh

Table 6 lists all measured sources of nitrogen to Phillips Creek Marsh. Annual rates of mineralization and nitrogen fixation were calculated by multiplying seasonally measured values (Table 2) by the number of days for that season. Seasons were defined as: winter (January, February, March), temperatures $<10^{\circ} \mathrm{C}$; spring (April, May) and fall (September, October, November, December), temperatures 10 to $20^{\circ} \mathrm{C}$; summer (June, July, August), temperatures $>20^{\circ} \mathrm{C}$. Numbers of days in each range during 1994 were based upon the VCR database (Krovitz et al. 1994/1995) and

Table 5. Marsh sediment-water column nutrient exchanges (vegetated transect, Phillips Creek Marsh). Negative values indicate uptake of nutrients by sediments

\begin{tabular}{|c|c|c|c|}
\hline Month & $\begin{array}{l}\text { Average daily } \\
\text { inundation "(h) }\end{array}$ & $\begin{array}{c}\mathrm{NH}_{4}^{+} \text {flux } \\
\left(\mathrm{mm} \mathrm{m}^{-2} \mathrm{mo}^{-1}\right)\end{array}$ & $\begin{array}{c}\mathrm{NO}_{3}^{-} \text {flux } \\
\left(\mathrm{mm} \mathrm{m}^{-2} \mathrm{mo}^{-1}\right)\end{array}$ \\
\hline $\operatorname{Jan}$ & 3.5 & -3.85 & -3.30 \\
\hline Feb & 4.3 & -1.27 & -0.76 \\
\hline Mar & 5.4 & -6.45 & -34.81 \\
\hline Apr & 3.8 & -7.55 & -13.80 \\
\hline May & 7.1 & -9.18 & 13.92 \\
\hline Jun & 5.9 & -15.40 & -7.08 \\
\hline Jul & 5.7 & -25.21 & -5.69 \\
\hline Aug & 6.6 & -47.12 & -6.12 \\
\hline Sep & 7.9 & -73.69 & -6.00 \\
\hline Oct & 7.5 & -62.37 & -6.93 \\
\hline Nov & 8.9 & -31.86 & -12.74 \\
\hline Dec & 89 & -13.37 & -10.97 \\
\hline Annual & lux & -284.420 & -122.110 \\
\hline \multicolumn{4}{|c|}{$\begin{array}{l}\text { "Daily inundation based upon hourly measurements of } \\
\text { tidal height (mean sea level) in VCR database } \\
{ }^{\circ} \text { Calculated from measurements made by Neikirk (1996) }\end{array}$} \\
\hline
\end{tabular}


Table 6. Sources of nitrogen to Phillips Creek Marsh. Veg: Spartina alterniflora marsh; unveg: unvegetated creekbank site: ND: not determined. Standard errors determined for seasonal measurements given in parentheses; $n=6$ for mineralization $; \mathrm{n}=3$ for $\mathrm{N}$-fixation; $\mathrm{n}=5$ for water column fluxes

\begin{tabular}{|c|c|c|c|}
\hline DIN source & \multicolumn{2}{|c|}{$\begin{array}{c}\text { Contribution ( } \mathrm{g} \mathrm{N} \mathrm{m}^{-2} \mathrm{yr}^{-1} \text { ) } \\
\text { Veg }\end{array}$} & Comments, source \\
\hline Mineralization & $84(15)$ & $105(25)$ & Measured, this study \\
\hline Nitrogen fixation & $1(0.4)$ & $0.20(0.04)$ & Measured, this study \\
\hline $\begin{array}{l}\text { Water column flux } \\
\text { Ammonium } \\
\text { Nitrate }\end{array}$ & $\begin{array}{r}4(0.4) \\
1.7(0.3)\end{array}$ & $N^{*}$ & $\begin{array}{l}\text { Measured, this study, } \\
\text { Neikirk }(1996)\end{array}$ \\
\hline Atmospheric deposition & 0.43 & 0.43 & Paerl (1995) \\
\hline Sediment import & 1.25 & 8 & Kastler (1993) \\
\hline Totals & 92 & 114 & \\
\hline \multicolumn{4}{|c|}{$\begin{array}{l}\text { ¿Exchanges between overlying water and creek bank sites were measured } \\
\text { during July, November, and February. A substantial flux of } \mathrm{NH}_{4}^{+} \text {from sedi- } \\
\text { ments to overlying water of } 812 \mu \mathrm{g} \mathrm{N} \mathrm{m} \mathrm{N}^{-2} \mathrm{~h}^{-1}(\mathrm{SE}=301, \mathrm{n}=5 \text { ) was observed } \\
\text { during July; however, during November and February diffusive fluxes were } \\
\text { from overlying water into the sediments }\end{array}$} \\
\hline
\end{tabular}

$10 \mathrm{~cm}$ of a North Inlet, SC, Spartina alterniflora marsh (Whiting \& Morris 1986).

Hourly fluxes of DIN between sediments and overlying tidal water measured by Neikirk (1996) using in situ chambers were scaled up to daily fluxes by multiplying by the average daily period of inundation in hours calculated for a month. Monthly rates were sums of daily fluxes for that month, and values for missing months were estimated by linear interpolation (Table 5).

DIN sources from atmospheric deposition were based on measurements made by Paerl (1995) in North Carolina and Delaware. The value shown in Table 6 and Fig. 1 represents the sum of $\mathrm{NH}_{4}{ }^{+}$and $\mathrm{NO}_{3}{ }^{-}$.

Sediment import to a site adjacent to our Phillips Creek study site was measured by Kastler (1993) several years

were: winter $=90 \mathrm{~d}$; spring $=61 \mathrm{~d}$; fall $=122 \mathrm{~d}$; and summer $=92 \mathrm{~d}$. Measured $\mathrm{N}$-cycling rates during February, May, October, and July were used to calculate seasonal rates (winter, spring, fall, and summer, respectively).

Annual rates of gross $\mathrm{N}$ mineralization for the vegetated site, $84 \mathrm{~g} \mathrm{~N} \mathrm{~m}^{-2}$ ( $\mathrm{SE}=15$ for $\mathrm{n}=6$ ), and for the unvegetated creekbank site, $105 \mathrm{~g} \mathrm{~N} \mathrm{~m}^{-2}$ ( $\mathrm{SE}=25$ for $\mathrm{n}=6$ samples), were based upon seasonally measured mineralization values, corrected for temperature variation within seasons by using the van't Hoff equation and a $Q_{10}$ of 2, measured in July 1994. Average daily air temperatures were obtained from the VCR database (Krovitz et al. 1994/1995). The annual rate was also corrected for an average daily temperature variation of $3^{\circ} \mathrm{C}$ across the sediment profile measured by Blum (1993) in Phillips Creek Marsh. Mineralization was integrated over a $10 \mathrm{~cm}$ depth interval, since Gross et al. (1991) observed that in short-form Spartina alterniflora salt marshes located in Virginia $83 \%$ of live biomass was distributed fairly evenly over the top $10 \mathrm{~cm}$ of sediment.

Sources of $\mathrm{NO}_{3}{ }^{-}$to the sediment, either nitrification (Table 2) or diffusion from overlying tidal water (Table 5), were generally small; thus, there was little $\mathrm{NO}_{3}{ }^{-}$available for conversion to $\mathrm{NH}_{4}{ }^{+}$by dissimilatory nitrate reduction. We have, therefore, assumed that any $\mathrm{NH}_{4}^{+}$produced in sediments and measured using the ${ }^{15} \mathrm{NH}_{4}{ }^{+}$isotope pool dilution technique represented that released primarily by gross nitrogen mineralization.

Nitrogen fixation was integrated over a depth interval of $10 \mathrm{~cm}$ since approximately $80 \%$ of acetylene reduction activity was shown to take place within the top prior to this study. Annual sediment accumulations were $0.64 \mathrm{~g} \mathrm{~cm}^{-2}$ for the vegetated interior marsh and $6.7 \mathrm{~g} \mathrm{~cm}^{-2}$ for the creek bank. These accumulation rates overestimate sediment import since they include resuspended sediment. Percent organic matter varied from $8-15 \%$ (vegetated) to 6-8\% (creek bank). Values for sediment input were multiplied by $\% \mathrm{~N}$ found in fresh creek bank, unvegetated sediments $10.17 \%$, Table 3) during July 1994.

\section{Sinks of dissolved inorganic nitrogen in Phillips Creek Marsh}

Calculation of sinks for DIN in Phillips Creek Marsh (Table 7) were based upon the following:

Aboveground macrophyte $\mathrm{N}$ demand $114 \mathrm{~g} \mathrm{~N} \mathrm{~m}^{-2}$ $\mathrm{yr}^{-1}$ ) was calculated assuming that the measured $\mathrm{AGB}$ of $427 \mathrm{~g} \mathrm{DW} \mathrm{m}^{-2}$ (average July and August, Table 3) turns over 1.5 times per year as discussed in Morris \& Haskin (1990). The calculated aboveground production rate (AGP) of $641 \mathrm{~g} \mathrm{DW} \mathrm{m}^{-2} \mathrm{yr}^{-1}$ was multiplied by $2.1 \% \mathrm{~N}$ (average of July and August measurements, Table 3) measured in Spartina alterniflora leaves.

Belowground macrophyte $\mathrm{N}$ demand $126 \mathrm{~g} \mathrm{~N} \mathrm{~m}^{-2}$ $\mathrm{yr}^{-1}$ ) was based upon root ingrowth studies using litter bags performed by Blum (1993) at a Phillips Creek Marsh site close to our own. Blum measured net root production of $2143 \mathrm{~g} \mathrm{~m}^{-2} \mathrm{yr}^{-1}$, equivalent to a $35 \%$ turnover of our measured MOM of $6179 \mathrm{~g} \mathrm{DW} \mathrm{m}^{-2}$, assuming that belowground MOM is in steady state. Nitrogen demand was calculated by multiplying percent turnover by $1.2 \% \mathrm{~N}$ (average of $\% \mathrm{~N}$ in roots and rhizomes for July and August, Table 3). 
Fig. 1. A conceptual, process-based nitrogen mass balance model for a Spartina alterniflora-vegetated salt marsh. (Virginja Coast Reserve, Phillips Creek, VA, USA). AGB: aboveground biomass; $B G B$ : belowground biomass

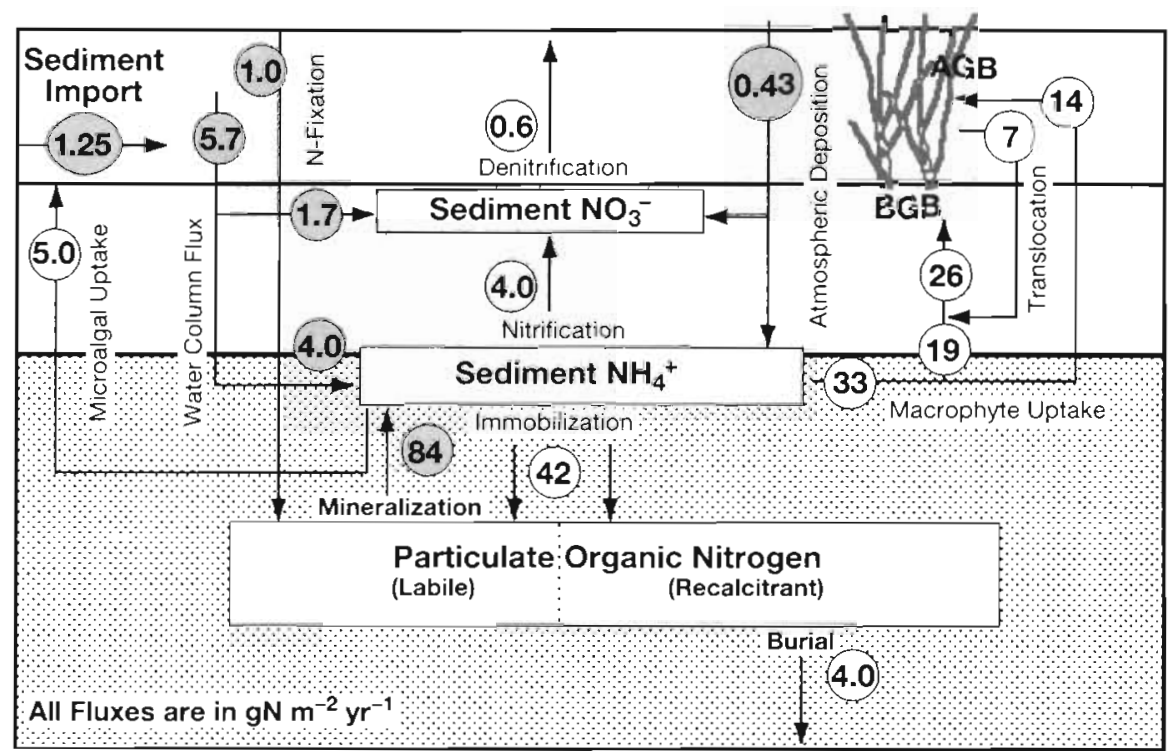

We subtracted from the macrophyte $\mathrm{N}$ demand an amount of $\mathrm{N}$ ( $\left.7 \mathrm{~g} \mathrm{~N} \mathrm{~m}^{-2} \mathrm{yr}^{-1}\right)$ which we estimated would be supplied by translocation from $A G B$. The $N$ available for either translocation or leaching $\left(7 \mathrm{~g} \mathrm{~m}^{-2} \mathrm{yr}^{-1}\right)$ was calculated by multiplying AGP (641 $\mathrm{g} \mathrm{DW} \mathrm{m}^{-2}$ $\mathrm{yr}^{-1}$ ) by the average \% $\mathrm{N}$ measured in leaves during July-August (2.1\%) and December (0.98\%, Table 3). Hopkinson \& Schubauer (1984) determined that half of the total $\mathrm{N}$ in AGP is translocated to the roots; thus, we assumed that the entire $7 \mathrm{~g} \mathrm{~N}$ was translocated to the roots, and we ignored the possibility of leaching losses.

$\mathrm{N}$-uptake by benthic microalgae $\left(5 \mathrm{~g} \mathrm{~N} \mathrm{~m}^{-2} \mathrm{yr}^{-1}\right)$ was calculated using chlorophyll a concentrations mea- sured bimonthly in the top $5 \mathrm{~mm}$ of sediment (Table 4) and converted to biomass-specific production rates using the model of Pinckney \& Zingmark (1993a, b). Carbon fixation during production was converted to nitrogen demand using the Redfield ratio of $5.68 \mathrm{~g} \mathrm{C}$ $g \mathrm{~N}^{-1}$. As mentioned above we verified the applicability of Pinckney's model to Phillips Creek Marsh by measuring gross sediment microalgal $\mathrm{CO}_{2}$ fixation during July.

Sediment burial of nitrogen ( $4 \mathrm{~g} \mathrm{~N} \mathrm{~m}^{-2} \mathrm{yr}^{-1}$ ) was estimated assuming that accretion must keep pace with an annual sea level rise of $3.5 \mathrm{~mm}$ (Oertel et al. 1989). Units of nitrogen in buried sediment were calculated

Table 7. Sinks of DIN, Phillips Creek Marsh. Interior marsh vegetated with short-form Spartina alterniflora. Standard errors determined for seasonal measurements given in parentheses; $\mathrm{n}=5$ for macrophyte uptake; $\mathrm{n}=10$ for microalgal uptake; $\mathrm{n}=3$ for nitrification and denitrification

\begin{tabular}{|c|c|c|}
\hline DIN $\sin k$ & 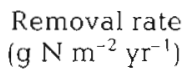 & Comments \\
\hline Macrophyte uptake - aboveground & $14(1.9)$ & $\begin{array}{l}=\% \mathrm{~N} \times 1.5 \text { turnover rate } \times 427 \mathrm{~g} \mathrm{DW} \mathrm{m}^{-2} \text { biomass (measured this study), } \\
\% \mathrm{~N}=2.1\end{array}$ \\
\hline Macrophyte uptake - belowground & $19(5)$ & $\begin{array}{l}=\% \mathrm{~N} \times 0.35 \text { turnover } \times 6179 \mathrm{~g} \mathrm{DW} \mathrm{m}^{-2} \text { macro-organic matter (MOM) } \\
\text { minus the } \mathrm{N} \text { translocated from aboveground biomass (AGB) (measured } \\
\text { this study). \% } \mathrm{N}=1.2 .35 \% \text { turnover based upon Blum's (1993) measure- } \\
\text { ment of root production. Half of the } \mathrm{N} \text { in } \mathrm{AGB} \text { was assumed to be trans- } \\
\text { located belowground }\end{array}$ \\
\hline Microalgal uptake - sediment & $5(0.7)$ & $\begin{array}{l}\text { Based on sediment chlorophyll a measured bimonthly (this study) and } \\
\text { calculated using model of Pinckney (1994) }\end{array}$ \\
\hline Sediment burial & 4 & $\begin{array}{l}\text { Assuming accretion must keep up with annual } 3.5 \mathrm{~mm} \text { sea level rise. } \\
\% \mathrm{~N}=0.1743\end{array}$ \\
\hline Microbial immobilization & 42 & Assumes that the $\mathrm{N}$ immobilized equals the $\mathrm{N}$ mineralized from $\mathrm{AGB}+\mathrm{MOM}$ \\
\hline Denitrification & $0.6(0.15)$ & Measured, this study \\
\hline Nitrification & $4(1.5)$ & Measured, this study \\
\hline Total DIN sink & 89 & \\
\hline
\end{tabular}


based on dry bulk density $\left(0.7 \mathrm{~g} \mathrm{~cm}^{-3}\right.$, Table 1) and $0.174 \% \mathrm{~N}$ (average May and July, Table 3) in fresh creekbank sediment measured in this study.

Microbial immobilization was estimated based upon the premise that it is tightly coupled to mineralization as discussed in Benner et al. (1991). In the model presented here we propose that an amount of $\mathrm{NH}_{4}{ }^{+}$equal to half that produced during gross mineralization of sediment particulate organic matter (POM) $\left(42 \mathrm{~g} \mathrm{~N} \mathrm{~m}^{-2}\right.$ $\mathrm{Yr}^{-1}$ ) is subsequently immobilized from sediments, most likely by bacteria. This rate of immobilization is suggested by Benner et al.'s (1991) observation that approximately $50 \%$ of the $\mathrm{N}$ in Spartina alterniflora belowground detritus is derived from exogenous sources during diagenesis. Furthermore, with this rate of immobilization sources and sinks of DIN in Phillips Creek marsh are approximately in balance as is supported by the lack of observed export of DIN.

Nitrogen may be immobilized biotically into bacterial biomass or bacterial exudates such as exoenzymes attached to plant biomass, or it may be immobilized abiotically by incorporation into humified complexes (Benner et al. 1991, White \& Howes 1994). Furthermore, we suggest that $N$ can be immobilized into 2 types of pools, a pool with a high $\mathrm{C} / \mathrm{N}$ ratio that is associated with macrophyte detritus and turns over slowly and a pool with a low $\mathrm{C} / \mathrm{N}$ ratio that is labile and turns over rapidly. If all of the nitrogen mineralized were derived from macrophyte detrital material, it would require decomposition of $>6000 \mathrm{~g}$ DW to account for the $84 \mathrm{~g} \mathrm{~N} \mathrm{~m}^{-2} \mathrm{yr}^{-1}$ mineralized in vegetated sediments. Since we can account for only $2803 \mathrm{~g}$ DW MOM $+\mathrm{AGB}$ available for decomposition, we suggest that approximately half of the mineralized $N$ must be supplied by turnover of a labile pool of sediment organic $\mathrm{N}$. Since the $\mathrm{C} / \mathrm{N}$ ratio in bacteria reportedly ranges from 3 to 10 (Linley \& Newell 1984), bacterial biomass or its exudates are a likely source of the mineralized nitrogen observed in our study that we cannot account for by turnover of MOM or AGB.

Annual rates of nitrification $\left(4 \mathrm{~g} \mathrm{~N} \mathrm{~m}^{-2}\right)$ and denitrification $\left(0.6 \mathrm{~g} \mathrm{~N} \mathrm{~m}^{-2}\right)$ were estimated as described above for nitrogen fixation and mineralization. Nitrification was integrated over a depth profile of $2 \mathrm{~cm}$ and denitrification over $10 \mathrm{~cm}$

DIN sinks for the unvegetated creek bank sites include benthic microalgal uptake, and export to overlying tidal water by diffusion and to ebbing water by advection. Based upon sediment chlorophyll measurements made during July and December, benthic microalgal uptake was $30 \%$ lower in unvegetated than in vegetated sediments (Table 4). Diffusive exchanges of DIN between the sediments and creek water were measured during daytime in July, November, and February (Neikirk 1996, data not shown). A substan- tial flux of $\mathrm{NH}_{4}^{+}$from sediments to overlying water of $812 \mu \mathrm{g} \mathrm{N} \mathrm{m}^{-2} \mathrm{~h}^{-1}$ ( $\mathrm{SE}=301, \mathrm{n}=5$ ) was observed during July; however, during November and February diffusive fluxes were small and appeared to be from overlying water into the sediments.

\section{DISCUSSION}

To our knowledge there have been only a few attempts to develop process-based nitrogen mass balance models for either salt (DeLaune et al. 1983, Hopkinson \& Schubauer 1984) or freshwater marshes (Morris \& Bowden 1986). Fig. 1 summarizes all sources and sinks of inorganic nitrogen that we and others have measured in a short-form Spartina alterniflora marsh located on the Eastern Shore of Virginia. One of the benefits of developing such a model is that it provides a clear understanding of which processes dominate and what rates are the most uncertain. It is clear that in this particular marsh DIN turns over very rapidly because of high gross mineralization rates throughout the year; however, it is not clear what mechanisms are responsible for sequestering mineralized DIN, since based upon chamber measurements of sediment-water column fluxes little $\mathrm{N}$ appears to be exported from this marsh (Table 5). Plant uptake is a major sink, but accounts for only half of the DIN mineralized. Moreover, whereas mineralization rates vary little throughout the year, plant uptake occurs only during the growing season (April-September) in Virginia. There must then be a mechanism for temporarily immobilizing DIN into a pool which will be available to supply the $\mathrm{NH}_{4}{ }^{+}$required for plant uptake in the spring.

Of the estimates that we have made in our model the most uncertain are macrophyte uptake, variations in mineralization through the sediment profile, microalgal productivity, and microbial immobilization. Estimation of above- and belowground macrophyte production has proved problematic for many investigators, varying by as much as 3 -fold for the same marsh depending upon the computational method used (Shew et al. 1981). Our value for aerial net macrophyte production of $641 \mathrm{~g} \mathrm{~m}^{-2} \mathrm{yr}^{-1}$ falls within the range observed by many others for various U.S. East Coast marshes (Gallagher et al. 1980, Dai \& Wiegert 1996b). Similarly the value quoted for net belowground production of $2163 \mathrm{~g} \mathrm{~m}^{-2} \mathrm{yr}^{-1}$ is not out of the range published by others (Blum 1993). However, recent attempts to more accurately constrain net total macrophyte primary production (NTPP) based upon the physiological capacity of Spartina alterniflora (Morris et al. 1984, Dai \& Wiegert 1996a) suggest that most estimates made using various harvest techniques over- 
estimate NTPP. For example, Dai \& Wiegert (1996a) calculated a NTPP for a short-form $S$. alterniflora marsh in Georgia of $749 \mathrm{~g} \mathrm{C} \mathrm{m}^{-2} \mathrm{yr}^{-1}$. Morris et al. (1984) determined theoretical maximum net belowground production values of 600,600 , and $1400 \mathrm{~g} \mathrm{C}$ $\mathrm{m}^{-2} \mathrm{yr}^{-1}$ for Sippewisset, MA, Flax Pond, NY, and Sapelo, GA, marshes respectively, compared to our measured value of $809 \mathrm{~g} \mathrm{C} \mathrm{m}^{-2} \mathrm{yr}^{-1}$ based upon an average value for $\% \mathrm{C}$ in roots and rhizomes of 37.4 (Table 3). Our value for NTPP of $1121 \mathrm{~g} \mathrm{C} \mathrm{m}^{-2} \mathrm{yr}^{-1}$ falls at the upper limit of the maximum values quoted by Dai \& Wiegert; thus, our calculation of macrophyte $\mathrm{N}$ uptake (33 $\mathrm{g} \mathrm{N} \mathrm{m}^{-2} \mathrm{yr}^{-1}$ ) may overestimate the true value.

Another possible source of error in our estimate of belowground macrophyte uptake of $\mathrm{N}$ is the calculation of $\mathrm{N}$ translocated from $\mathrm{AGB}$ to roots of $7 \mathrm{~g} \mathrm{~N} \mathrm{~m}^{-2}$ (based upon difference of $N$ in leaves during JulyAugust and December). We have assumed that little $N$ is lost by leaching. We did not measure leaching rates from leaves, and estimates of $\mathrm{N}$ lost by leaching vary widely from $14 \mathrm{~g} \mathrm{~N} \mathrm{~m}^{-2} \mathrm{yr}^{-1}$ for a Louisiana marsh (Turner 1993) to $5.6 \mathrm{~g} \mathrm{~N} \mathrm{~m}^{-2} \mathrm{yr}^{-1}$ for a Massachusetts marsh (Valiela \& Teal 1979) to $0.7 \mathrm{~g} \mathrm{~N} \mathrm{~m}^{-2} \mathrm{yr}^{-1}$ for a Georgia marsh (Hopkinson \& Schubauer 1984). If $N$ loss by leaching is important in this marsh, our calculation of the $\mathrm{N}$ required to support belowground production (BGP) would be an underestimate.

Our measured values for sediment chlorophyll (Table 4) and the calculated annual rate of microalgal production based upon these values $\left(28 \mathrm{~g} \mathrm{C} \mathrm{m}^{-2}, 5 \mathrm{~g} \mathrm{~N}\right.$ $\mathrm{m}^{-2}$ ) are lower than what has been reported by others. Pomeroy (1959) observed annual gross microalgal production of $200 \mathrm{~g} \mathrm{C} \mathrm{m}^{-2}$ in Georgia marshes, and Pinckney \& Zingmark (1993a) estimated annual production of $234 \mathrm{~g} \mathrm{C} \mathrm{m}^{-2}$ in a North Inlet, SC, short-form Spartina alterniflora marsh. However, standard errors for our chlorophyll measurements were low, and $\mathrm{CO}_{2}$ fixation rates measured during July verified productivity rates measured using July chlorophyll values, suggesting that the value given for microalgal uptake is reasonable.

Coupled nitrification-denitrification rates measured at Phillips Creek Marsh were low relative to mineralization rates and in the range reported by others (Lindau \& DeLaune 1991). We are quite confident of the rates given for nitrification; however, the value given for denitrification may underestimate the true rate. Because concentrations of $\mathrm{NO}_{3}{ }^{-}$in Phillips Creek are low during most of the year, denitrification in Phillips Creek Marsh is constrained by the nitrification rate. In addition, we have observed (unpubl. data) in ${ }^{15} \mathrm{~N}$ tracer experiments that rates of dissimilatory $\mathrm{NO}_{3}{ }^{-}$reduction to $\mathrm{NH}_{4}^{+}$are similar to those for denitrification; thus, coupled nitrification-denitrification is not likely to be an important sink for DIN in Phillips Creek Marsh.
For estimates of gross mineralization we assumed that the rates which we measured using cores ranging from 3 to $4 \mathrm{~cm}$ in depth were constant over the top $10 \mathrm{~cm}$ of sediment. We chose that depth interval for integration of the mineralization rate since Gross et al. (1991) observed that in short-form Spartina alterniflora salt marshes located in Virginia $46 \%$ of live $B G B$ occurred in the top $5 \mathrm{~cm}$ and $38 \%$ over the depth interval 5 to $10 \mathrm{~cm}$. The remaining $16 \%$ of live biomass occurred over the interval of 10 to $25 \mathrm{~cm}$. Blum (1993), using a litter bag technique to study decomposition in Phillips Creek Marsh, did not observe any significant differences in rates of decomposition of roots and rhizomes (collected from the top $20 \mathrm{~cm}$ of sediment) over the depth interval of 0 to $40 \mathrm{~cm}$ of sediment. We, thus, assumed that since live BGB was distributed fairly evenly over the top $10 \mathrm{~cm}$ of sediment, gross mineralization of that live biomass could reasonably be integrated over $10 \mathrm{~cm}$. On the other hand, Schubauer \& Hopkinson (1984) in a Georgia S. alterniflora marsh observed that the distribution and biomass of $S$. alterniflora roots, rhizomes, and MOM through the sediment profile to $30 \mathrm{~cm}$ changed dramatically from season to season. Bowden (1984), in a freshwater marsh in Massachusetts, observed an exponential decline in gross mineralization over the top $10 \mathrm{~cm}$ of sediment profile. Howes et al. (1985), in a Massachusetts salt marsh, observed that $74 \%$ of $\mathrm{CO}_{2}$ production and $66 \%$ of the root and rhizome standing stock were in the top 0 to $5 \mathrm{~cm}$ of the sediment profile. We believe that our choice of a $10 \mathrm{~cm}$ depth over which to normalize the measured mineralization rate was a reasonable one for a Virginia salt marsh; however, if we overestimated gross mineralization, the $\mathrm{N}$ avaílable for immobilization would similarly have been overestimated.

There are few values of microbial $\mathrm{N}$ immobilization reported in the literature, although it is thought to be an important sink for $\mathrm{NH}_{4}^{+}$in marsh sediments (Hopkinson \& Schubauer 1984, Linley \& Newell 1984, Bowden 1986) and estuarine waters (Thayer 1974). White \& Howes (1994) observed that during decay of aboveground ${ }^{15} \mathrm{~N}$-labelled Spartina alterniflora in litter bags, $50 \%$ of the total detrital $\mathrm{N}$ pool remained after $1 \mathrm{yr}$, and 50 to $65 \%$ of that pool was from exogenous sources (a pool other than macrophyte detrital material). Similarly, Benner et al. (1991) in studies of diagenesis of belowground $S$. alterniflora noted a loss of $58 \%$ of the initial $\mathrm{N}$ in roots and rhizomes during the first $120 \mathrm{~d}$ of decomposition, followed by an increase of $\% \mathrm{~N}$ to $>100 \%$ during the last $430 \mathrm{~d}$ of decomposition. Changes in stable isotope composition observed during this time suggested that exogenous $\mathrm{NH}_{4}{ }^{+}$immobilization was the source of this N. In other studies of bacterial growth on lignocellulose derived from $S$. alterniflora with a $\mathrm{C} / \mathrm{N}$ ratio of 56 , Benner et al. (1988) 
calculated that the theoretical maximum bacterial growth efficiency was approximately $10 \%$; however, actual growth efficiencies were 3 -fold higher. Thus, exogenous sources of $N$ (immobilization) would be required to support observed bacterial growth. In attempts to study loss versus retention of ${ }^{15} \mathrm{~N}$-labelled DIN over long time periods, White \& Howes (1994) in New England and DeLaune et al. (1983) in Louisiana both observed long-term retention of added labelled DIN in the sediment organic $N$ pool $152 \%$ after 3 growing seasons in Louisiana and $40 \%$ after 7 growing seasons in Massachusetts). These studies all suggest that immobilization of DIN represents an important process in marsh sediments.

In order to explain the resuits observed by White \& Howes (1994) and Benner et al. (1991) an amount of DIN equal to the DIN mineralized from AGB + MOM would have to be immobilized into or onto macrophyte detritus during decomposition. In other words, half of the $84 \mathrm{~g}$ of $\mathrm{NH}_{4}{ }^{+}-\mathrm{N}$ produced annually by gross mineralization is reimmobilized into organic matter, which is likely to be made up of microbial biomass plus exudates formed by that biomass (Rice \& Hanson 1984, Benner et al. 1991, Buchsbaum et al. 1991). This pool would be expected to turn over rapidly because of its low C/N ratio (Linley \& Newell 1984). Using decomposition rates for dead root and rhizome material $(0.0036$ aboveground and 0.0025 belowground during Year 1) measured by Blum (1993) in Phillips Creek Marsh, we have calculated that decomposition might annually provide $23.5 \mathrm{~g} \mathrm{~N} \mathrm{~m}^{-2}$ belowground and $17.7 \mathrm{~g} \mathrm{~N} \mathrm{~m}^{-2}$ aboveground (without taking into account leaching or translocationj. In addition, we have calculated, as described in Linley \& Newell (1984), that if $84 \mathrm{~g} \mathrm{~N}$ is mineralized from POM with an average $\mathrm{C} / \mathrm{N}$ ratio of $1 / 30,252 \mathrm{~g} \mathrm{~N}$ would be required to produce a $50 \%$ yield of bacteria with a $\mathrm{C} / \mathrm{N}$ ratio of $1 / 10 ; 126 \mathrm{~g} \mathrm{~N}$ would be required for a $25 \%$ yield of bacteria $(\mathrm{C} / \mathrm{N}$ ratio of $1 / 20$ ). Although this is a crude calculation, it does indicate that substantial amounts of $\mathrm{N}$ must be immobilized to support growth of bacteria involved in mineralizing POM. Since decomposition of AGB + MOM accounts for less than half of the $\mathrm{NH}_{4}{ }^{+}$produced by mineralization in Phillips Creek Marsh, we suggest that the remaining $\mathrm{NH}_{4}{ }^{+}$is remineralized from a labile pool of microbial organic $N$ which has been immobilized during mineralization of detrital material.

Inputs of DIN to Phillips Creek Marsh were $92 \mathrm{~g} \mathrm{~N}$ $\mathrm{m}^{-2} \mathrm{yr}^{-1}$ to the vegetated marsh and $114 \mathrm{~g} \mathrm{~N} \mathrm{~m}^{-2} \mathrm{yr}^{-1}$ to the unvegetated creek bank (Table 6). Sinks for DIN in the vegetated marsh equalled $89 \mathrm{~g} \mathrm{~N} \mathrm{~m}^{-2} \mathrm{yr}^{-1}$ (Table 7) and were in close balance with sources, as we had predicted for this marsh. We do not show a calculated sink term for the creek bank site since we lacked sufficient data on diffusive and advective fluxes from that site to tidal water. However, without a macrophyte sink at the unvegetated creek bank we would expect export of DIN from that site.

The head of Phillips Creek lies approximately $2 \mathrm{~km}$ northwest of our study site in a Spartina patens marsh. There is no perennially flowing surface water connection between Phillips Creek and the surrounding watershed. Nitrogen contributions to the study site from the watershed during intermittent periods of surface flow would be mediated by the creek and were thus accounted for in tidal exchange studies (Neikirk 1996). Overland flow from diffuse sources was assumed to be negligible because topographic slope is less than 0.005 , and a 20 to $40 \mathrm{~m}$ wide, nearly continuous forested buffer zone separates the agricultural fields from the marsh creek.

The variable salinities observed in shallow ground water at the upland-marsh border suggest the possibility that portions of Phillips Creek Marsh may receive some direct groundwater discharge. However, low concentrations of $\mathrm{NO}_{3}{ }^{-}$and $\mathrm{NH}_{4}{ }^{+}$(at low salinities) in these groundwaters and in pore waters underlying the study site would make any resultant $\mathrm{N}$-flux small. The low hydraulic conductivity of marsh and creek sediments (as evidenced by the inability to obtain piezometer samples or measure seepage fluxes) at and near our site suggests that little groundwater is discharged directly to the study area. However, approximately 150 to $300 \mathrm{~m}$ from the site there exists high $\mathrm{NO}_{3}{ }^{-}$discharge from springs and a sandy, erosional creek bank that enters the creek but does not contact the marsh directly. The volume of localized high $\mathrm{NO}_{3}{ }^{-}$seepage is small relative to the total volume of the creek, occurs only at low tide during periods of high water table, and undergoes substantial dilution during flood tide (Neikirk 1996); thus, its contribution to the $N$-mass balance is accounted for in the tidal flux.

Exchanges of DIN between unvegetated creek bank sites and the adjacent creek can occur via diffusive flux from sediments to overlying water at high tide followed by surface runoff and by advective flux of sediment pore water to the creek bottom at ebb tide. If benthic microalgal uptake (5 $\mathrm{g} \mathrm{N} \mathrm{m}^{-2} \mathrm{yr}^{-1}$. Table 4), nitrification (4 $\mathrm{g} \mathrm{N} \mathrm{m}^{-2} \mathrm{yr}^{-1}$, Table 7), and microbial immobilization (53 $\mathrm{g} \mathrm{N} \mathrm{m}^{-2} \mathrm{yr}^{-1}=0.5 \times$ mineralization rate, Table 6) are the major sinks for DIN, each $\mathrm{m}^{2}$ of unvegetated creek bank could potentially export a surplus of $52 \mathrm{~g} \mathrm{~N} \mathrm{yr}^{-1}$ or $64 \mathrm{mg} \mathrm{N} \mathrm{m}^{-2}$ tide $^{-1}$. The diffusive exchange from creek bank sites measured using flux chambers during July (Neikirk 1996) was $2.4 \mathrm{mg} N$ $\mathrm{m}^{-2}$ tide $^{-1}$. Thus, surplus nitrogen in creek bank sites was lost as either PON, DON, by herbivory, or as DIN by advection of sediment pore water during ebb tide. During July concentrations of $\mathrm{NH}_{4}{ }^{+}$in the creek water were $27 \mu \mathrm{M}$ at slack before flood tide in the early 
morning (Neikirk 1986). We have calculated that if all the surplus $\mathrm{NH}_{4}{ }^{+}$in $1 \mathrm{~m}^{2}$ of creek bank (calculated on a daily basis) were exported to $1 \mathrm{~m}$ of creek bottom (width of $10 \mathrm{~m}$ ) to a depth of 5 to $10 \mathrm{~cm}$ in advected pore water it would account for 17 to $34 \%$ of the $\mathrm{NH}_{4}^{+}$ observed at ebb tide, depending upon the depth of water in the creek at maximum ebb. Although advection may be important for export of excess DIN from unvegetated creek bank sites, such sites represent a small percentage of total marsh surface area. Howes \& Goehringer (1994) in Great Sippewissett Marsh, MA, and Whiting \& Childers (1989) in a North Inlet, SC, marsh measured advection from creekbanks and similarly concluded that export of DIN from the creekbank is quantitatively unimportant.

\section{CONCLUSIONS}

We had hypothesized that mainland marshes such as Phillips Creek Marsh which have been continuously vegetated for hundreds of years and which receive only small inputs of 'new' nitrogen from groundwater, surface water runoff, the atmosphere, tidal creek, sediment import, and nitrogen-fixation must have a conservative nitrogen cycle. Results of the abovedescribed study support this hypothesis. Whereas gross mineralization supplied far more ammonium than was required to support macrophyte and microalgal uptake, exchanges of DIN between the marsh and overlying water and losses due to coupled nitrification/denitrification did not account for the surplus ammonium. We propose that in order to maintain steady state in the system approximately half of the DIN mineralized is immobilized into a readily remineralizable microbial organic $\mathrm{N}$ pool. Since mineralization and macrophyte uptake are temporally out of phase, the labile microbial organic $\mathrm{N}$ pool would serve to temporarily sequester ammonium until it is required for plant uptake. Since immobilization appears to be a major process regulating ammonium availability and exchange potential in salt marshes, the study of $\mathrm{N}$ immobilization should be a strong focus for future studies of marsh $\mathrm{N}$-cycling.

Acknowledgements. We express our thanks to the many colleagues and graduate students that helped with this work: Dr Hans Paerl and Matt Fitzpatrick, University of North Caroline, Institute of Marine Science, who performed ethylene analyses for us; Dr R. Christian and the analytical laboratory at East Carolina University for $\mathrm{C} / \mathrm{N}$ analyses; Ms Trine Christensen, University of Virginia, for her great help with marsh surveys; Dr Mary Firestone, Paul Brooks, and Don Herman, University of California, Berkeley, for their great assistance with development of ${ }^{15} \mathrm{~N}$-isotope dilution techniques; Dr John Porter, University of Virginia, for his help with the LTER data- base; Dr Ting Dai, Virginia Institute of Marine Science, Dr Linda Blum, University of Virginia, and Dr R. Christian for their critical reviews of the manuscript. We appreciate the help of Emily Sax, Peter Paik, and David Christian, funded by the NSF REU program for their field assistance. In addition, we thank David Miller, Scott Neubauer, Bill Seufzer, David Fugate, and Chris Buzzelli for their excellent help in the field. This work was supported by NSF grant DEB 94-20183 to Virginia Institute of Marine Science and a NSF LTER grant DEB 94-11974 to the University of Virginia. VIMS contribution \#2095.

\section{LITERATURE CITED}

Axelrad DM (1974) Nutrient flux through the salt marsh ecosystem. PhD dissertation, College of William and Mary, Gloucester Point, VA

Benner R, Fogel ML, Sprague EK (1991) Diagenesis of belowground biomass of Spartina alterniflora in salt-marsh sediments. Limnol Oceanogr 36:1358-1374

Benner R, Lay J, K'nees E, Hodson, RE (1988) Carbon conversion efficiency for bacterial growth on lignocellulose: implications for detritus-based food webs. Limnol Oceanogr 33:1514-1526

Blum LK (1993) Spartina alterniflora root dynamics in a Virginia marsh. Mar Ecol Prog Ser 102:169-178

Bowden WB (1984) A nitrogen-15 isotope dilution study of ammonium production and consumption in a marsh sediment. Limnol Oceanogr 29:1004-1015

Bowden WB (1986) Nitrification, nitrate reduction, and nitrogen immobilization in a tidal freshwater marsh sediment. Ecology 67:88-99

Brooks PD, Herman DJ, Atkins GJ, Prosser SJ, Barrie A (1993) Rapid, isotopic analysis of selected soil gases at atmospheric concentrations. In: Harper LA, Mosier AR, Duxbury JM (eds) Agricultural ecosystem effects on trace gases and global climate change. American Society of Agronomy, Madison, WI, p 193-202

Brooks PD, Stark JM, Mclnteer BB, Preston T (1989) Diffusion method to prepare soil extracts for automated nitrogen-15 analysis. Soil Sci Soc A.m J 53:1707-1711

Buchsbaum R, Valiela I, Swain T, Dzierzeski M, Allen S (1991) Available and refractory nitrogen in detritus of coastal vascular plants and macroalgae. Mar Ecol Prog Ser 72 : $131-143$

Chambers RM (1992) A fluctuating water-level chamber for biogeochemical experiments in tidal marshes. Estuaries 15:53-58

Childers DL (1994) Fifteen years of marsh flumes - a review of marsh - water column interactions in Southeastern USA estuaries. In: Mitsch W (ed) Global wetlands. Elsevier Publ, Amsterdam, p 277-294

Childers DL, Cofer-Shabica S, Nakashima L (1993a) Spatial and temporal variability in marsh-water column interactions in a southeastern USA salt marsh estuary. Mar Ecol Prog Ser 95:25-38

Childers DL, Day JW (1988) Direct quantification of nutrient and material fluxes between microtidal gulf coast wetlands and the estuarine water column. Estuar Coast Shelf Sci 27:483-494

Childers DL, McKellar HN, Dame RF, Sklar FH, Blood ER (1993b) A dynamic nutrient budget of subsystem interactions in a salt marsh estuary. Estuar Coast Shelf Sci 36:105-131

Dai T, Wiegert R (1996a) Estimation of the primary productivity of Spartina alterniflora using a canopy model. 
Ecography 19:410-423

Dai T, Wiegert RG (1996b) Ramet population dynamics and net aerial primary productivity of Spartina alterniflora. Ecology 77:276-288

Dame RF, Gardner LR (1993) Nutrient processing and the development of tidal creek ecosystems. Mar Chem 43: $175-183$

Dame RF, Kenny PD (1986) Variability of Spartma alterniflora primary production in the euhaline North Inlet estuary. Mar Ecol Prog Ser 32:71-80

Davidson EA. Stark JM, Firestone MK (1990) Microbial production and consumption of nitrate in an annual grassland. Ecology 71:1968-1975

de la Cruz AA (1965) A study of particulate organic detritus in a Georgia salt marsh estuarine ecosystem. PhD dissertation, University of Georgia, Athens

DeLaune RD, Smith CJ, Patrick, WH (1983) Nitrogen losses from a Louisiana Gulf Coast salt marsh. Estuar Coast Shelf Sci $17: 133-141$

Gallagher JL, Reimold RJ, Linthurst RA, Pfeiffer WJ (1980) Aerial production, mortality, and mineral accumulationexport dynamics in Spartina alterniflora and Juncus roemerianus plant stands. Ecology 61:303-312

Gross MF, Hardisky MA, Wolf PL, Klemas V (1991) Relationship between aboveground and belowground biomass of Spartina alterniflora (Smooth Cordgrass). Estuaries 14 $180-191$

Hopkinson CS, Schubauer JP (1984) Static and dynamic aspects of nitrogen cycling in the salt marsh graminoid Spartina alterniflora. Ecology 65:961-969

Howes BL. Goehringer DD (1994) Porewater drainage and dissolved organic carbon and nutrient losses through the intertidal creekbanks of a New England salt marsh. Mar Ecol Prog Ser 114:289-301

Howes BL, Dacey JWH, Teal JM (1985) Annual carbon mineralization and belowground production of Spartina alterniflora in a New England salt marsh. Ecology 66:595-605

Kastler JA (1993) Sedimentation and landscape evolution of Virginia salt marshes. MS thesis, University of Virginia, Charlottesville

Krovitz DK, Porter JH, Richardson DL (1994/1995) Meleorological measurements of the Virginia Coast Reserve LTER. Data of the Virginia Coast Reserve Long Term Ecological Research Project. University of Virginia, Charlottesville

Lee DR, Cherry JA (1978) Six methods for estımating in situ ground water seepage in lakes. $J$ Geol Educ 27:6-10

Libelo EL, MacIntyre WG (1994) Effects of surface-water movement on seepage-meter measurements of flow through the surface-water interface. Appl Hydrogeol 2: $49-54$

Lindau CW, DeLaune RD (1991) Dinitrogen and nitrous oxide emission and entrapment in Spartina alterniflora salt marsh soils following addition of $\mathrm{N}-1.5$ labelled ammonium and ritrate. Estuar Coast Shelf Sci 32:161-172

Linley EAS, Newell RC (1984) Estimates of bacterial growth yields based on plant detritus. Bull Mar Sci 35:409-425

Lorenzen C (1967) Determination of chlorophyll and phaeopigments: spectrophotometric equations. Limnol Oceanogr 12:343-346

MacMillin KM, Blum LK, Mills AL (1992) Comparison of bacterial dynamics in tidal creeks of the lower Delmarva Peninsula, Virginia, USA. Mar Ecol Prog Ser 86:111-121

Moore KA (1974) Carbon transport in two York River, Virginia marshes. MS thesis, University of Virginia, Charlottesville

Morris JT (1980) The nitrogen uptake kunetics of Spartina alterniflora in culture. Ecology 61:1114-1121

Morris JT (1982) A model of growth responses by Spartina alterniflora to nitrogen limitation. J Ecol 70:25-42

Morris JT (1989) Modelling light distrubution within the canopy of the marsh grass Spartina alterniflora as a function of canopy biomass and solar angle. Agric For Meteorol 46:349-361

Morris JT, Bowden WB (1986) A mechanistic, numerical model of sedimentation, mineralization, and decomposition for marsh sediments. Soil Sci Soc Am J 50:96-105

Morris JT, Haskin B (1990) A 5-yr record of aerial primary production and stand characteristics of Spartina alterniflora. Ecology 71:2209-2217

Morris JT, Houghton RA, Botkin DB (1984) Theoretical limits of belowground production by Spartina alterniflora: an analysis through modelling. Ecol Model 26:155-175

Neikirk BB (1996) Exchanges of dissolved inorganic nitrogen and dissolved organic carbon between salt marsh sediments and overlying tidal water MA thesis, College of William and Mary, Gloucester Point, VA

Nixon SW (1980) Between coastal marshes and coastal waters - a review of twenty years of speculation and research on the role of salt marshes in estuarine productivity and water chemistry. In: Hamilton P, MacDonald KB (eds) Estuarine and wetland processes. Plenum Press, New York, p $437-525$

Odum EP, de la Cruz AA (1967) Particulate organic detritus in a Georgia salt marsh-estuarine ecosystem. In: Lauff GH (ed) Estuaries. American Association for the Advancement of Science, Washington, DC, p 383-388

Oertel GF, Wong GTF, Conway JD (1989) Sediment accumulation at a fringe marsh during transgression, Oyster, Virginia. Estuaries 12:18-26

Paerl H (1995) Coastal eutrophication in relation to atmospheric nitrogen deposition: current perspectives. Ophelia $41: 237-259$

Patrick WH, DeLaune RD (1976) Nitrogen and phosphorus utilization by Spartina alterniflora in a salt marsh in Barataria Bay, Louisiana. Estuar Coast Mar Sci 4:59-64

Perstorp (1992) Nitrate + nitrite in seawater. Perstorp Analytical Corporation, Wilsonville, OR

Pinckney J (1994) Development of an irradiance-based ecophysiological model for intertidal benthic microalgal production. In: Krumbein WE, Paterson DM, Stal LJ (eds) Biostabilization of sediments. Oldenburg

Pinckney JL, Zingmark RG (1994) Comparison of highperformance liquid chromatographic, spectrophotometric, and fluorometric methods for determining chlorophyll a concentrations in estuarine sediments. $J$ Microbiol Methods 19:59-66

Pinckney JL, Zingmark RG (1993a) Modeling the annual production of intertidal benthic microalgae in estuarine ecosystems. J Phycol 29:396-407

Pinckney JL, Zingmark RG (1993b) Biomass and production of benthic microalgal communities in estuarine habitats. Estuaries 16:887-897

Pomeroy LR (1959) Algal productivity in salt marshes of Georgia. Limnol Oceanogr 4:386-397

Rice DL, Hanson RB (1984) A kinetic model for detritus nitrogen: role of the associated bacteria in nitrogen accumulation. Bull Mar Sci 35:326-340

Schubauer JP, Hopkinson CS (1984) Above- and belowground emergent macrophyte production and turnover in a coastal marsh ecosystem, Georgia. Limnol Oceanogr 29: 1052-1065

Scudlark JR, Church TM (1989) The sedimentary flux of nutrients at a Delaware salt marsh site: a geochemical perspective. Biogeochemistry (Dordr) 7:55-75

Shew DM, Linthurst RA, Seneca ED (1981) Comparison of 
production methods in a southeastern North Carolina Spartina alterniflora salt marsh. Estuaries 4:97-109

Solorzano L (1969) Determination of ammonia in natural waters by the phenolhypochlorite method. Limnol Oceanogr 14: $799-801$

Teal JM (1962) Energy flow in the salt marsh ecosystem of Georgia. Ecology 43:614-624

Thayer GW (1974) Identify and regulation of nutrients limiting phytoplankton production in the shallow estuaries near Beaufort, N.C. Oceologia 14:75-92

Turner RE (1993) Carbon, nitrogen, and phosphorus leaching rates from Spartina alterniflora salt marshes. Mar Ecol Prog Ser 92:135-140

Turner RE, Boesch DF (1987) Aquatic animal production and wetland relationships. In: Hook DD (ed) Ecology and management of wetlands. Croon Helms, Beckenham, Kent, p 25-39

Valiela I, Teal JM (1980) Inputs, outputs and interconversions of nitrogen in a salt marsh ecosystem. In: Jefferies RL, Davy AJ (eds) Ecological processes in coastal environments. Blackwell Sci Publ, Oxford, p 399-419

Valiela I, Teal JM (1974) Nutrient limitation in salt marsh vegetation. In: Reimold RJ, Queen WH (eds) Ecology of halophytes. Academic Press, New York, p 547-563

Valiela I, Teal JM, Volkman S, Shafer D, Carpenter EJ (1978) Nutrient and particulate fluxes in a salt marsh ecosystem: tidal exchanges and inputs by precipitation and groundwater. Limnol Oceanogr 23:798-812

Weiss RF, Price BA (1980) Nitrous oxide solubility in water and seawater. Mar Chem 8:347-359

Wessel WW, Tietema A (1992) Calculating gross $N$ transfor-

Editorial responsibility: Gordon Thayer (Contributing

Editor), Bedufort, North Carolina, USA mation rates of ${ }^{15} \mathrm{~N}$ pool dilution experiments with acid forest litter: analytical and numerical approaches. Soil Biol Biochem 24:931-942

White DS, Howes BL (1994) Nitrogen incorporation into decomposing litter of Spartina alterniflora. Limnol Oceanogr 39:133-140

White DS, Howes BL (1994) Long-term ${ }^{15} \mathrm{~N}$-nitrogen retention in the vegetated sediments of a New England salt marsh. Limnol Oceanogr 39:1878-1892

Whiting GJ, Childers DL (1989) Subtidal advective water flux as a potentially important nutrient input to southeastern U.S.A. salt marsh estuaries. Estuar Coast Shelf Sci 28: $417-431$

Whiting GJ, McKellar HN, Spurrier JD, Wolaver TG (1989) Nitrogen exchange between a portion of vegetated salt marsh and the adjoining creek. Limnol Oceanogr 34 : $463-473$

Whiting GJ, Morris JT (1986) Nitrogen fixation $\left(\mathrm{C}_{2} \mathrm{H}_{2}\right.$ reduction) in a salt marsh: its relationship to temperature and an evaluation of an in situ chamber technique. Soil Biol Biochem 18:515-521

Winter TC, Labaugh JW, Rosenberry DO (1991) The design and use of a hydraulic potentiomanometer for direct measurement of differences in hydraulic head between groundwater and surface water Limnol Oceanogr 33: $1209-1214$

Wolaver TG, Wetzel RL, Zieman JC, Webb KL (1983) Tidal exchange of nitrogen and phosphorus between a mesohaline vegetated marsh and the surrounding estuary in the Lower Chesapeake Bay. Estuar Coast Shelf Sci 16: $321-332$

Submitted: January 17, 1997; Accepled: August 26, 1997 Proofs received from author(s): November 19, 1997 